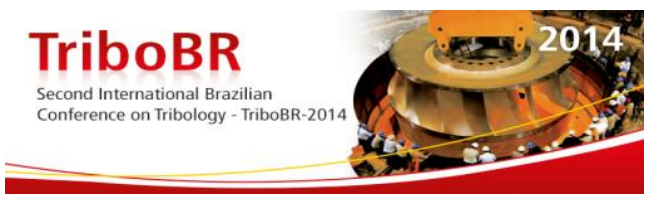

\title{
CAVITATION EROSION RESISTANCE OF ACTIVE SCREEN- LOW TEMPERATURE PLASMA NITRIDED AISI 410 MARTENSITIC STAINLESS STEEL*
}

\author{
Luis Armando Espitia ${ }^{1}$ \\ Hanshan Dong² \\ Xiao-Ying $\mathrm{Li}^{3}$ \\ Carlos Eduardo Pinedo ${ }^{4}$ \\ André Paulo Tschiptschin ${ }^{5}$
}

\begin{abstract}
AISI 410 martensitic stainless steel specimens were low temperature plasma nitrided at $400{ }^{\circ} \mathrm{C}$ in a mixture of $75 \% \mathrm{~N}_{2}: 25 \% \mathrm{H}_{2}$, during $20 \mathrm{~h}$. Active screen technic was used to avoid any edge effect The nitrided case is composed of expanded martensite ( $\left.\alpha^{\prime} \mathrm{N}\right)$ and $\varepsilon-\mathrm{Fe}_{3} \mathrm{~N}$ iron nitride, whilst chromium nitride precipitation was avoided. Surface hardness reached $1275 \mathrm{HV} 0.01$. The transverse microhardness profile shows a gentle hardness gradient with a NHT nitrided case depth of $28 \mu \mathrm{m}$. Nanoindentation tests were carried out in order to assess the hardness $(H)$, the Young modulus $(E)$, the $H / E$ and $\mathrm{H}^{3} / \mathrm{E}^{2}$ ratios and the elastic recovery $\left(\mathrm{W}_{\mathrm{e}}\right)$ of both nitrided and non-nitrided specimens. The cavitation erosion mass losses were measured as a function of exposure time. The results showed a decrease of 27 times of the mass loss compared to the non-nitride specimens. Wear rate decreased from $2.56 \mathrm{mg} / \mathrm{h}$ for the non-nitrided condition to $0.085 \mathrm{mg} / \mathrm{h}$ after nitriding. The increment in the elastic recovery and the higher hardness values are responsible for the greater cavitation erosion resistance exhibited by the expanded martensite. Such results showed that low temperature plasma nitriding and the formation of expanded martensite are effective to increase cavitation erosion resistance of AISI 410 stainless steel.
\end{abstract}

Keywords: Martensitic stainless steel; Cavitation erosion; Active screen plasma nitriding.

1 MSc, PhD student, Metallurgical and Materials Engineering Department, University of São Paulo, São Paulo, SP, Brazil.

2 PhD, Professor, Surface Engineering Research Group, University of Birmingham, Birmingham, WM, UK.

$3 \quad P h D$, Surface Engineering Research Group, University of Birmingham, Birmingham, WM, UK.

4 PhD, Technical Director, Heat Tech, Technologies for Heat Treatment and Surface Engineering, Mogi das Cruzes, SP, Brazil.

5 MSc, PhD, Dr habil., Professor, Metallurgical and Materials Engineering Department, University of São Paulo, São Paulo, SP, Brazil.

* Technical contribution to the $2^{\text {nd }}$ International Brazilian Conference on Tribology - TriboBR 2014, November $3^{\text {rd }}$ to $5^{\text {th }}$, 2014, Foz do Iguaçu, PR, Brazil. 


\section{INTRODUCTION}

Plasma nitriding is a thermochemical treatment that involves the diffusion of nitrogen through metals. This treatment has been widely used to improve wear and hardness of stainless steels without impairing their corrosion resistance. However, some limitations such as the edge effect, arcing surface damage and the hollow cathode effect have demanded the introduction of additional technology on plasma nitriding. Accordingly, the active screen technic (ASPN) was developed to overcome those disadvantages. In this nitriding process, the cathodic potential is applied to a cage that surrounds the worktable; the plasma is formed on it instead of being formed on the surface of the parts to be treated, allowing a better control in the nitrogen potential during the treatment. The wear behavior of plasma nitrided martensitic stainless steel has been assessed by several authors in different tribological systems [1-3], enhancing, for instance, the sliding and rolling wear resistance (AISI $440 \mathrm{C}$ ) and the dry erosion resistance (AISI 420). However, few works dealing with the cavitation erosion resistance of low temperature plasma nitrided martensitic stainless steel has been published. In a previous paper Espitia et al [4] reported the cavitation erosion behavior of DC plasma nitrided AISI 410 stainless steel. In that work, a $25 \mu \mathrm{m}$ nitrided case, composed of expanded martensite and iron nitrides was formed. The iron nitrides precipitated in the first $5 \mu \mathrm{m}$ layer at the top of the case; beneath this region, expanded martensite was the only phase formed in the remaining $20 \mu \mathrm{m}$ case. In addition, longitudinal cracks were also observed in the $5 \mu \mathrm{m}$ deep region, probably due to the residual stresses induced by nitrogen diffusion. The cavitation erosion rate of the nitrided AISI 410 showed two different stages, a first one with a greater mass loss rate, corresponding to the wear of the $5 \mu \mathrm{m}$ region containing nitrides and small longitudinal cracks and a second one from 8 hours testing on corresponding to the precipitate free expanded martensite region. Once the $5 \mu \mathrm{m}$ nitrided case containing iron nitrides was removed, the $20 \mu \mathrm{m}$ expanded martensite case resisted the cavitation damage, decreasing the erosion rate exhibited at the beginning of the test. These results show that both the iron nitrides and the cracks in the nitrided case reduce the cavitation erosion resistance of DC plasma nitrided AISI 410 stainless steel. The aim of this work is to assess the cavitation erosion resistance of ASPN nitrided AISI 410 steel in terms of cumulative mass losses and wear rates for both nitrided and non-nitrided specimens and to compare these results with those obtained for DC plasma nitrided AISI 410 stainless steel.

\section{MATERIAL AND METHODS}

\subsection{Materials and Treatments}

AISI 410 specimens were austenitized at $1000^{\circ} \mathrm{C}$ during 1 hour, water quenched, tempered at $600^{\circ} \mathrm{C}$ for 1 hour and then air cooled to room temperature. Afterwards, the heat treated specimens were ground on emery papers from ASTM 100 to ASTM 1200. The nominal chemical composition is shown in table I.

Table 1. AISI 410 martensitic stainless steel nominal chemical composition (wt. \%)

\begin{tabular}{cccccc}
\hline $\mathrm{C}$ & $\mathrm{Cr}$ & $\mathrm{Ni}$ & $\mathrm{Mo}$ & $\mathrm{P}$ & $\mathrm{S}$ \\
\hline 0.13 & 12.40 & 0.30 & 0.08 & 0.029 & 0.002 \\
\hline
\end{tabular}

\footnotetext{
* Technical contribution to the $2^{\text {nd }}$ International Brazilian Conference on Tribology - TriboBR 2014, November $3^{\text {rd }}$ to $5^{\text {th }}$, 2014, Foz do Iguaçu, PR, Brazil.
} 


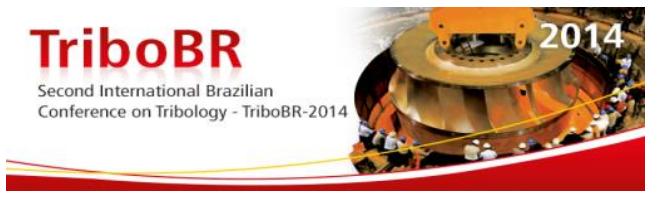

The thermochemical treatment was carried out in a Metal SA - Luxemburg reactor during 20 hours at $400^{\circ} \mathrm{C}$ in a mixture of $75 \%$ of nitrogen and $25 \%$ of hydrogen. Active screen technic was used to avoid any edge effect.

\subsection{Microstructure, Hardness and Phases Characterization}

The microstructure of the specimens before and after the plasma nitriding treatment was assessed by optical microscopy. The phases were identified by X-ray diffraction using Cu-Ka radiation $(\lambda=1.5418 \AA)$ and Bragg-Brentano $\theta-2 \theta$ configuration at $2 \theta$ scanning angles from 20 to 90 degrees. Vickers microhardness was measured on top of the nitrided case and on the cross section of the nitrided layer using a $10 \mathrm{gf}$ load. Nitrogen content as a function of depth was measured using wavelength dispersive spectrometry WDS, according to a procedure proposed by Toro and Tschiptschin [5]. Nanoindentation tests were carried out according to Oliver and Pharr [6] in order to assess the hardness $(H)$, the Young modulus $(E)$, the $H / E$ and $H^{3} / E^{2}$ ratios and the elastic recovery $\left(W_{e}\right)$ of both nitrided and non-nitrided specimens. 10 indentations in each specimen were carried out.

\subsection{Cavitation Erosion Tests}

Cavitation erosion tests were carried out according to ASTM G32 standard [7], holding the specimens at $500 \mu \mathrm{m}$ under the vibrating horn. The vibration frequency of the horn was $20 \mathrm{KHz}$ with $40 \mu \mathrm{m}$ peak-to-peak displacement amplitude. The tests were conducted during 20 hours with periodical interruptions, for registering the mass changes in order to obtain time-variation curves of the mass loss. Non-nitrided specimens of AISI 410 were used for comparison purposes. Each point in the mass loss curves corresponds to the average of three tests performed under the same conditions for both nitrided and non-nitrided specimens.

\section{RESULTS AND DISCUSSION}

Figure 1 shows the quenched and tempered AISI 410 martensitic stainless steel microstructure.

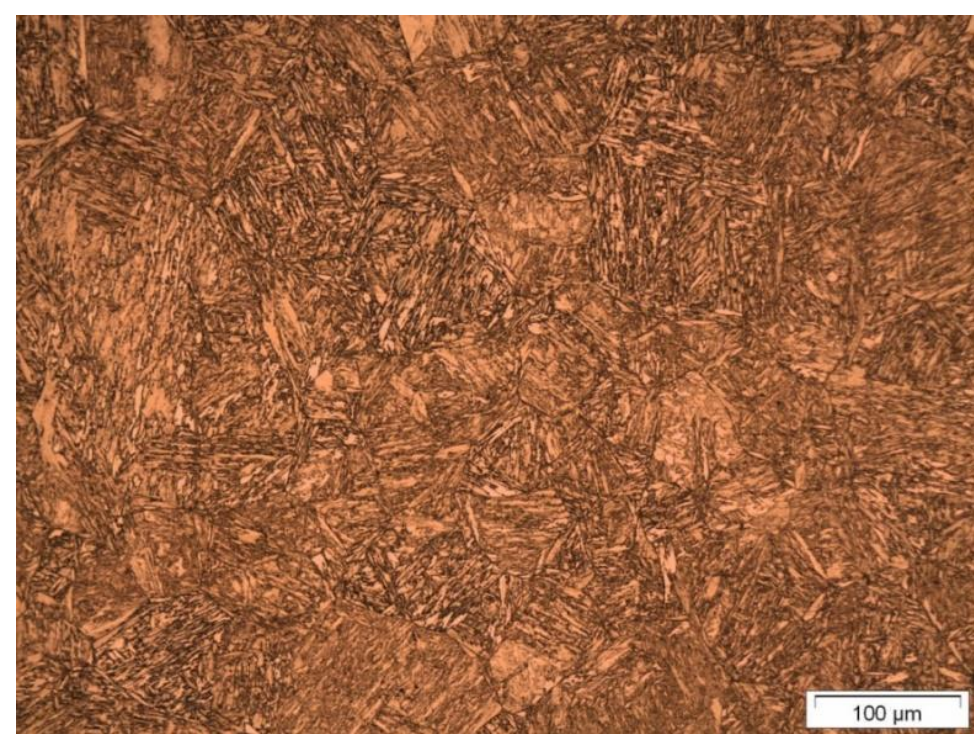

Figure 1. Microstructure of the quenched and tempered AISI 410 martensitic stainless steel composed of lath martensite.

* Technical contribution to the $2^{\text {nd }}$ International Brazilian Conference on Tribology - TriboBR 2014, November $3^{\text {rd }}$ to $5^{\text {th }}$, 2014, Foz do Iguaçu, PR, Brazil. 




The stainless steel microstructure is composed of tempered lath martensite with an average microhardness of $387 \pm 7$ HV0.01, as expected for that stainless steel and for the heat treatments conducted. Figures 2 and 3 show the cross-section of the active screen plasma nitrided and the DC plasma nitrided AISI 410 [4], respectively.

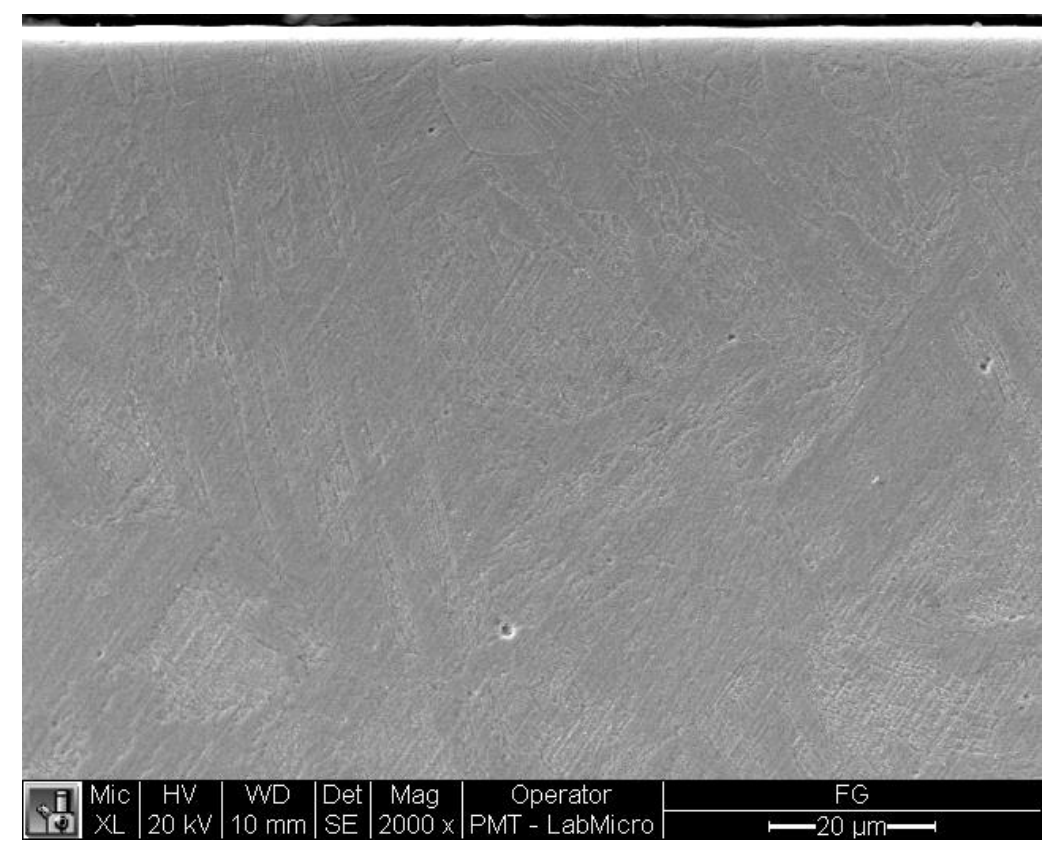

Figure 2. Cross-sectional view of the active screen-low temperature plasma nitrided AISI 410.

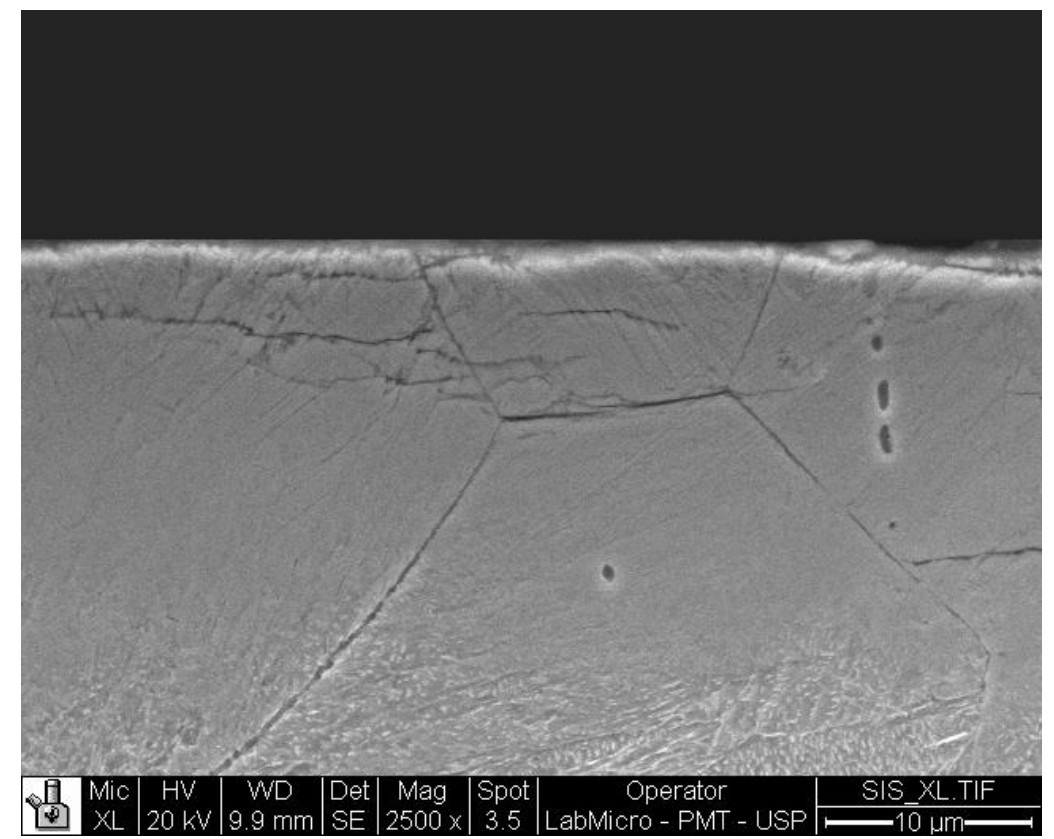

Figure 3. Cross-sectional view of the DC plasma nitrided AISI 410 [4].

It can be seen from figure 2 that the active screen nitrided case is free from cracks, which could appear due to stress induced by the atomic nitrogen supersaturation. No precipitated nitrides could be observed, either. In contrast, these features are evident in the DC nitrided AISI 410; acicular nitrides and cracks are located at the first $5 \mu \mathrm{m}$ of the nitrided case.

Furthermore, it can be seen from figures 2 and 3 that the interface between the metastable phase and the substrate is not evident. Some researchers inaccurately

* Technical contribution to the $2^{\text {nd }}$ International Brazilian Conference on Tribology - TriboBR 2014, November $3^{\text {rd }}$ to $5^{\text {th }}$, 2014, Foz do Iguaçu, PR, Brazil. 




relate that interface with the penetration depth of the nitrogen into the material. According to Christiansen and Somers [8], the nitrided case/substrate interface appears because of the sudden change on the nitrogen concentration (and as response to the chemical etching as well) and it is not a thermodynamic or crystallographic interface. According to the NHT criterion [9], the nitriding hardness depth is around $28 \mu \mathrm{m}$, as shown in figure 4.

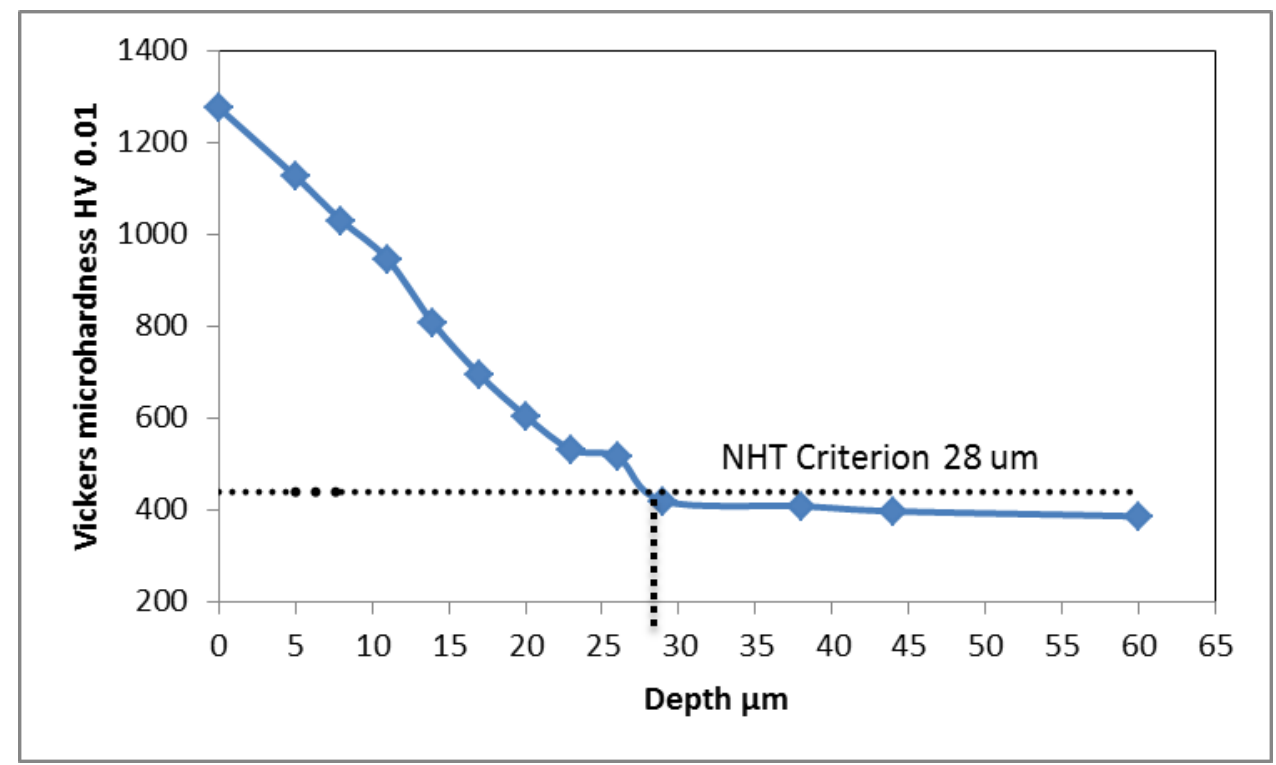

Figure 4. Transverse microhardness profile of the active screen-low temperature plasma nitrided AISI 410 evidencing the NHT criterion.

In addition, it can be seen in figure 4 that the microhardness gradient is gentle throughout the nitrided case. The maximum hardness value of $1275 \pm 92 \mathrm{HV} 0.01$ measured on the surface continuously decreases as a consequence of the reduction of the nitrogen content with depth, till the hardness of the substrate is achieved. Figure 5 shows the nitrogen content as a function of depth, measured by WDS.

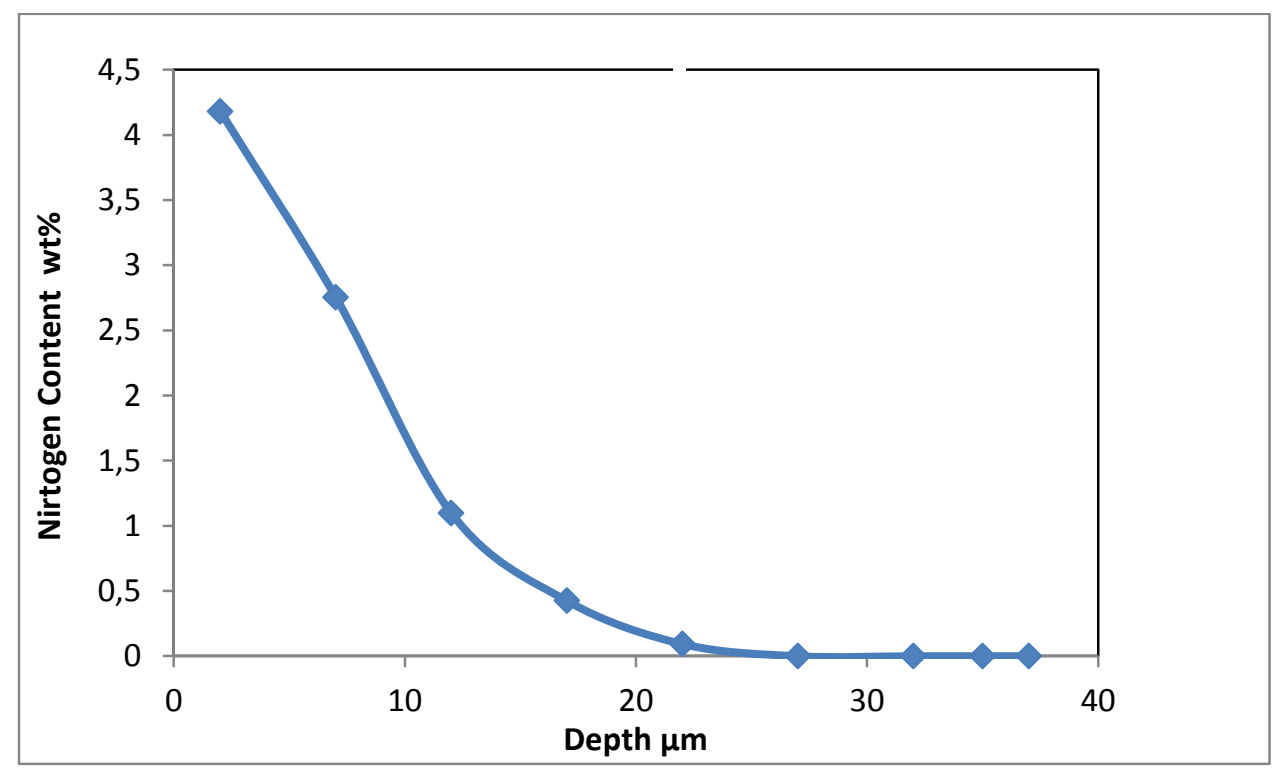

Figure 5. Nitrogen content as a function of depth measured by WDS.

* Technical contribution to the $2^{\text {nd }}$ International Brazilian Conference on Tribology - TriboBR 2014, November $3^{\text {rd }}$ to $5^{\text {th }}$, 2014, Foz do Iguaçu, PR, Brazil. 
The maximum nitrogen content of $4.2 \mathrm{wt} \%$ measured in $2 \mu \mathrm{m}$ depth continuously decreases to $\sim 0.1 \mathrm{wt} \%$ located at $26 \mu \mathrm{m}$ depth. These values reveal the nitrogen super saturation with values that exceed the nitrogen solubility in the crystal structure throughout the nitrided case. The high nitrogen content is responsible for the greater hardness values measured on top and in the transverse section of the nitrided case. It is worth mentioning that the nitrogen penetration measured by WDS is very close to the $28 \mu \mathrm{m}$ nitrided case thickness obtained by the NHT criterion.

Figure 6 shows the $X$ ray patterns of the quenched and tempered AISI 410 and the nitrided AISI 410 stainless steel.

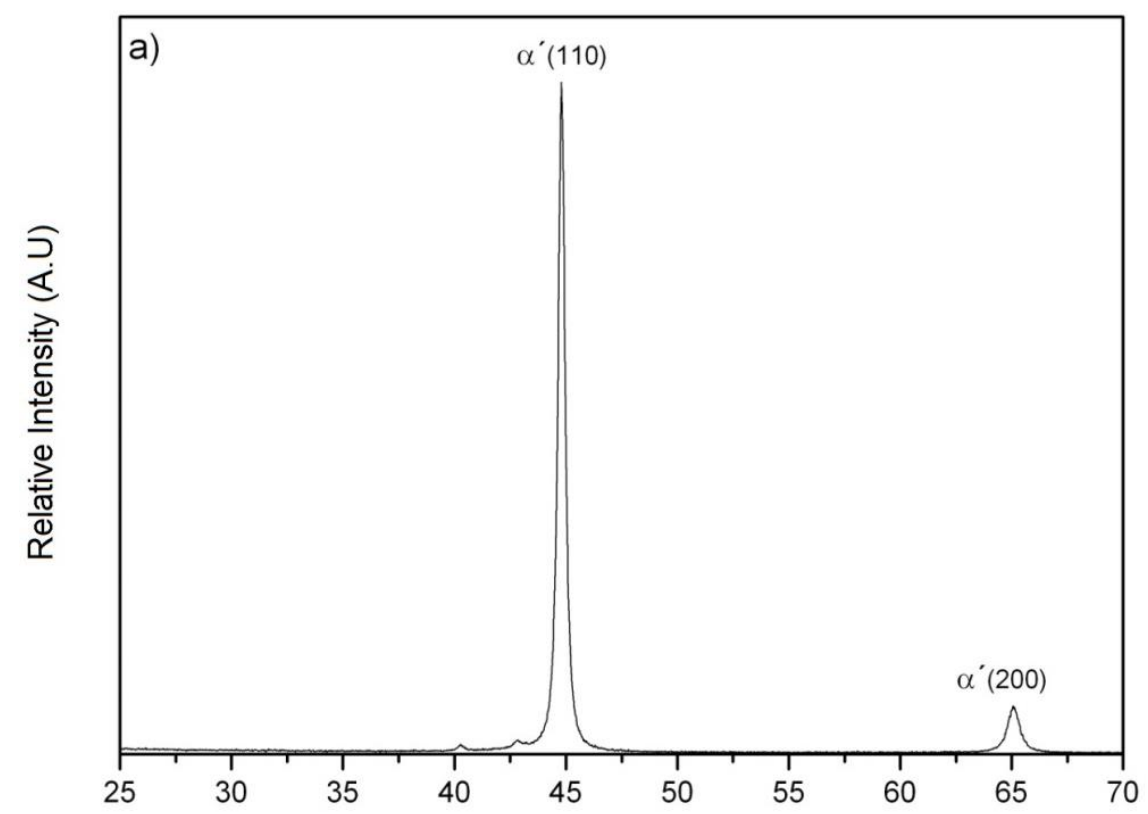

$2 \theta$

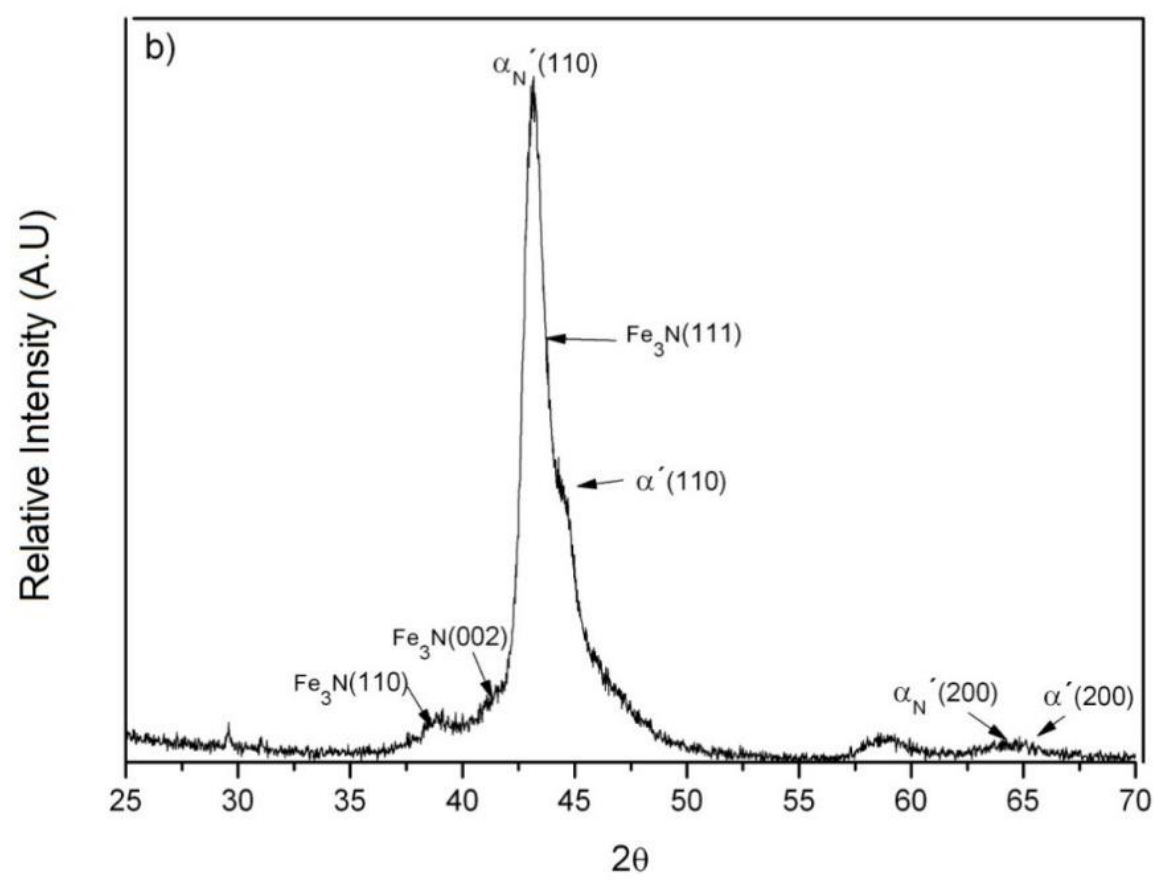

Figure 6a. X ray diffraction pattern of quenched and tempered AISI 410, b) active screen-low temperature plasma nitrided AISI 410.

* Technical contribution to the $2^{\text {nd }}$ International Brazilian Conference on Tribology - TriboBR 2014, November $3^{\text {rd }}$ to $5^{\text {th }}$, 2014, Foz do Iguaçu, PR, Brazil. 




The quenched and tempered AISI 410 showed the tempered martensite typical peaks located at $2 \theta$ angles $43.22^{\circ}$ and $65.09^{\circ}$. In the nitrided specimen one can see martensite peaks shifted to lower angles, probably due to nitrogen supersaturation in the interstitial sites of the crystal structure, leading to formation of a metastable nitrogen rich phase known as expanded martensite $\left(\alpha^{\prime} \mathrm{N}\right)[10,11,12]$. In addition to the expanded martensite peaks, it was also found $\varepsilon-\mathrm{Fe}_{3} \mathrm{~N}$ iron nitride peaks. It is worth noting that chromium nitride precipitation was not observed.

Figure 7 shows the time-variation mass loss curves of AISI 410 and of the nitrided AISI 410 stainless steel.

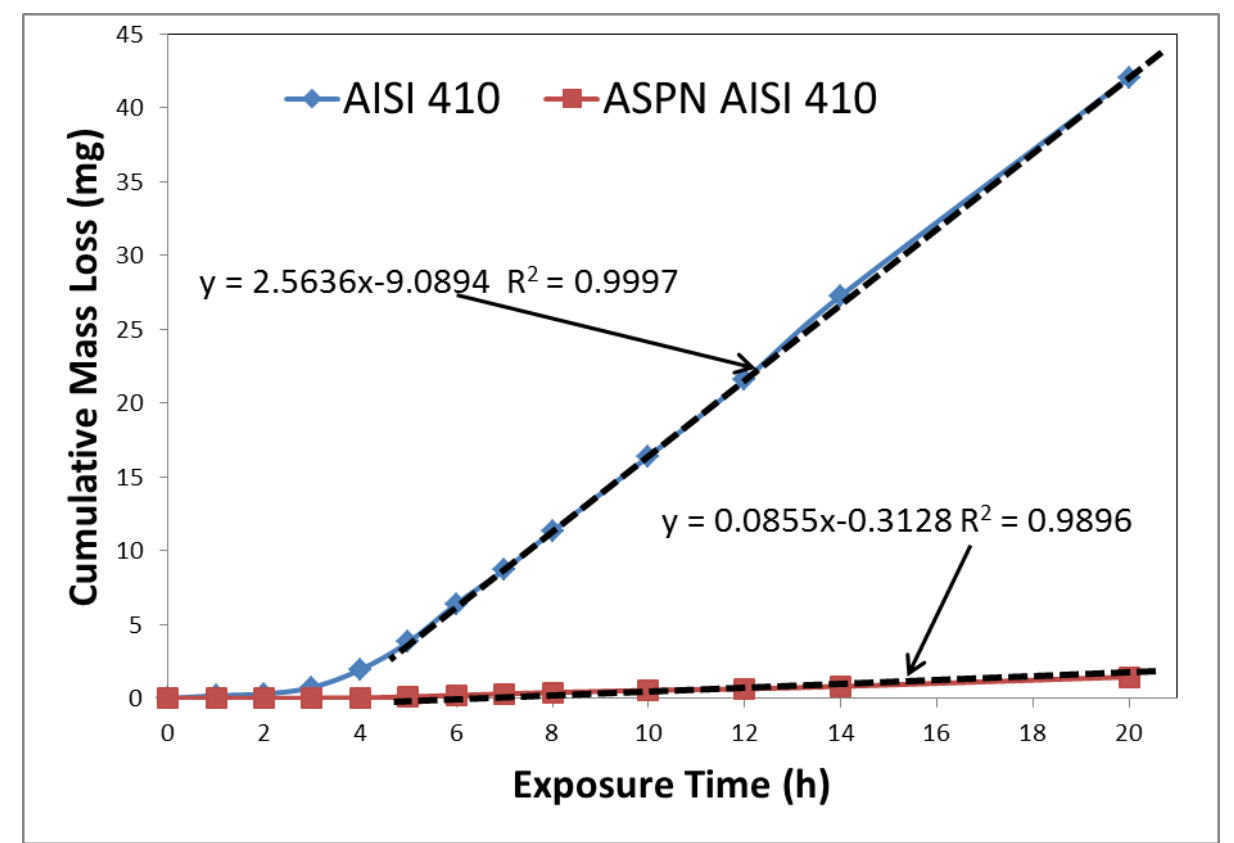

Figure 7. Time-variation mass loss curves OF AISI 410 and active screen-low temperature plasma nitrided AISI 410.

One can see in figure 7 that after 20 hours of testing the nitrided AISI 410 stainless steel showed the lowest cumulative mass loss with an average value of $1.5 \mathrm{mg}$. The AISI 410 martensitic stainless steel lost $42 \mathrm{mg}$, in other words, for the same testing time, the AISI 410 cumulative mass loss was 27 times greater than that of the nitrided AISI 410 stainless steel. Furthermore, the wear rate for each specimen was obtained from the slope of the straight line that best approximates the nearly linear steepest portion of the cumulative mass loss curves, as shown in figure 7 . The derivative of the equations $\mathrm{y}=2.5636 \mathrm{x}-9.0894$ (AISI 410) and $\mathrm{y}=0.0855 \mathrm{x}-0.3128$ (nitrided AISI 410) obtained from the straight lines plotted from the fifth hour on, corresponds to the wear rate for each material, that is, $2.56 \mathrm{mg} / \mathrm{h}$ and $0.085 \mathrm{mg} / \mathrm{h}$ for AISI 410 and nitrided AISI 410 respectively.

Table 2 shows the values of hardness, Young modulus and elastic recovery of the quenched and tempered and the active screen plasma nitrided AISI 410 steel measured by nanoindentation.

\footnotetext{
* Technical contribution to the $2^{\text {nd }}$ International Brazilian Conference on Tribology - TriboBR 2014, November $3^{\text {rd }}$ to $5^{\text {th }}$, 2014, Foz do lguaçu, PR, Brazil.
} 


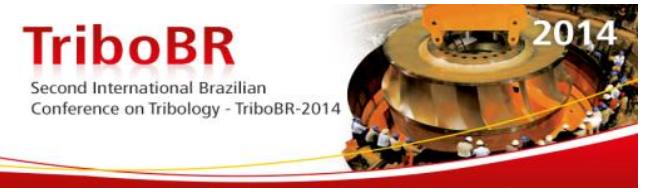

Table 2 Hardness, Young Modulus and Elastic Recovery of quenched and tempered AISI 410 and Active Screen Plasma Nitrided AISI 410

\begin{tabular}{|c|c|c|c|c|c|c|c|}
\hline \multicolumn{8}{|c|}{ AISI 410} \\
\hline & $\mathrm{E}(\mathrm{GPa})$ & $\mathrm{H}(\mathrm{GPa})$ & $\mathrm{H} / \mathrm{E}$ & $\begin{array}{l}\mathrm{H}^{3} / \mathrm{E}^{2} \\
(\mathrm{GPa})\end{array}$ & $\mathrm{h}_{\max }(\mathrm{nm})$ & $h_{f}(n m)$ & $\mathrm{W}_{\mathrm{e}}(\%)$ \\
\hline AVG & 189.3 & 4.68 & 0.025 & 0.003 & 234.3 & 197.7 & 15.7 \\
\hline STD & 6.37 & 0.24 & 0.0012 & 0.0004 & 5.9 & 6.6 & 0.9 \\
\hline \multicolumn{8}{|c|}{ Active Screen Plasma Nitrided AISI 410} \\
\hline & $\mathrm{E}(\mathrm{GPa})$ & $\mathrm{H}(\mathrm{GPa})$ & $\mathrm{H} / \mathrm{E}$ & $\begin{array}{l}\mathrm{H}^{3} / \mathrm{E}^{2} \\
(\mathrm{GPa})\end{array}$ & $\mathrm{h}_{\max }(\mathrm{nm})$ & $h_{f}(n m)$ & $\mathrm{W}_{\mathrm{e}}(\%)$ \\
\hline AVG & 191.5 & 13.67 & 0.071 & 0.070 & 148.4 & 81.4 & 45.1 \\
\hline STD & 7.4 & 0.75 & 0.003 & 0.008 & 3.8 & 4.2 & 1.6 \\
\hline
\end{tabular}

It can be seen in Table 2 that the addition of nitrogen had no effect in the Young modulus; the values of the tempered martensite and the expanded martensite were 189.3 GPa and 191.7 GPa, respectively. However, the hardness was increased from 4.68 GPa to 13.67GPa. Furthermore, the higher $\mathrm{H} / \mathrm{E}$ and $\mathrm{H}^{3} / \mathrm{E}^{2}$ ratios in the expanded martensite indicate a higher capacity of the nitrided case to resist high contact pressures typically found in hydraulic machinery submitted to cavitation erosion. Greater $\mathrm{H} / \mathrm{E}$ and $\mathrm{H}^{3} / \mathrm{E}^{2}$ ratios allow greater elastic deformations prior material failure by plastic deformation or cracking. In addition, the elastic recovery was increased from $15.7 \%$ to $45 \%$ indicating that during the cavitation erosion test, the expanded martensite was loaded in the elastic zone, reflecting the energy of the shock waves without undergoing plastic deformation. The elastic behavior and the higher hardness are responsible for the better cavitation erosion resistance exhibited by the expanded martensite. It has been reported that the cavitation erosion resistance is related to mechanical properties such as hardness, ultimate tensile strength, young modulus, fatigue strength and energy absorption characteristics.[13] Tschiptschin et al [14] measured the indentation work $\left(\mathrm{W}_{\mathrm{t}}\right)$ and the irreversible indentation work ( $\left.\mathrm{W}_{\text {irr }}\right)$ of a high temperature gas nitrided (HTGN) UNS S30403, using nanoindentation. These variables are related to the maximum indenter displacement $\left(h_{\max }\right)$ and to the final depth of contact after unloading $\left(\mathrm{h}_{\mathrm{f}}\right)$, respectively. They reported that the addition of

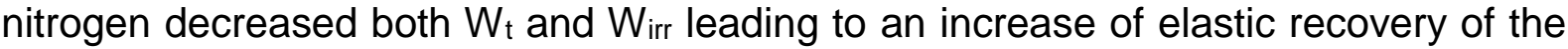
nitrided UNS S30403. Furthermore, they also showed a linear correlation between the mass loss rate during cavitation erosion and the inverse of the specific energy, both quantities were reduced with increasing amounts of nitrogen in solution, evidencing the beneficial effect of the addition of nitrogen in the cavitation erosion resistance of UNS S30403.

\section{CONCLUSION}

The nitrided case is composed of expanded martensite and $\varepsilon-\mathrm{Fe}_{3} \mathrm{~N}$ iron nitride, without any chromium nitride precipitation.

Surface hardness reached 1275 HV0.01. The transverse microhardness profile shows a gentle hardness gradient with a $28 \mu \mathrm{m}$ thick nitrided case.

AISI 410 cumulative mass loss was 27 times greater than that of the nitrided AISI 410 for the same testing time.

The wear rate decreased from $2.56 \mathrm{mg} / \mathrm{h}$ for the non-nitrided condition to $0.085 \mathrm{mg} / \mathrm{h}$ after nitriding.

* Technical contribution to the $2^{\text {nd }}$ International Brazilian Conference on Tribology - TriboBR 2014, November $3^{\text {rd }}$ to $5^{\text {th }}$, 2014, Foz do Iguaçu, PR, Brazil. 


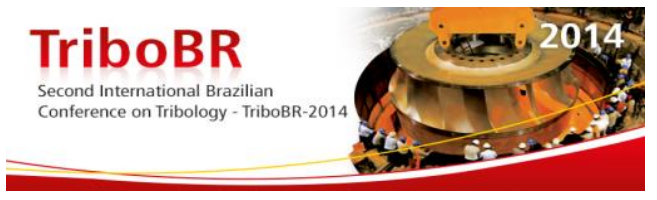

The addition of nitrogen had no effect in the Young modulus, $189.3 \mathrm{GPa}$ and 191.7 $\mathrm{GPa}$ for tempered martensite and expanded martensite, respectively. Hardness increased from 4.68 GPa to 13.67GPa.

The elastic recovery was increased from $15.7 \%$ to $45 \%$. The elastic behavior, the higher hardness and the absence of cracks and nitrides in the first $5 \mu \mathrm{m}$ of the nitrided case are responsible for the better cavitation erosion resistance exhibited by the expanded martensite microstructure.

Such results showed that the active screen low temperature plasma nitriding and the formation of expanded martensite are effective to increase cavitation erosion resistance of AISI 410 stainless steel.

\section{Acknowledgments}

The authors acknowledge the financial support from the São Paulo State Research Foundation, FAPESP, processes n. 2012/50890-0, and from National Research Foundation CNPQ processes n. 481918/2010-8 and 486104/2012-5.

\section{REFERENCES}

1 Y. Sun, T. Bell, G. Wood, Wear behavior of plasma-nitrided martensitic stainless steel, Wear 178 (1994) 131-138.

2 Y.T. Xi et al., Improvement of erosion and erosion-corrosion resistance of AISI420 stainless steel by low temperature plasma nitriding, Applied Surface Science 254 (2008) 5953-5958.

3 P. Corengia, et al., Friction and rolling-sliding wear of DC-pulsed plasma nitrided AISI 410 martensitic stainless steel, Wear 260 (2006) 479-485.

4 L.A Espitia, L. Varela, C.E. Pinedo, A.P. Tschiptschin, Cavitation erosion resistance of low temperature plasma nitrided martensitic stainless steel Wear, Volume 301, Issues 12, April-May 2013, Pages 449-456.

5 Toro A, Tschiptschin AP. Chemical characterization of a high nitrogen stainless steel by optimized electron probe microanalysis. Scripta Materialia 2010;63:803-6.

6 Oliver, W.C.; Pharr, G.M.; A new improved technique for determining hardness and modulus using load and sensitive indentation experiments, Journal of Materials Research, v7, p 1564-1582,1992.

7 American Society for Testing and Materials (ASTM) G32, Standard test method for cavitation erosion using vibratory apparatus, Annual book of ASTM standards 1998.

8 Christiansen, T.; Somers M. A. J.; Nitrogen diffusion and nitrogen depth profiles in expanded austenite: experimental assessment, numerical simulation and role of stress, Materials Science and Technology, v24, p.159-167, 2008.

9 DIN50190, Teil3:H"artetiefew"armebehandelter Teile Ermittlungder Nitrierh" artetiefe, (M"arz 1979).

10 S.K. Kim, et al., Characteristic of martensitic stainless steel nitrided in low- pressure RF plasma, Surface and Coating Technology 163-164 (2003) 380-385.

11 C.X. Li, T. Bell, Corrosion properties of plasma nitride AISI 410 martensitic stainless steel in $3.5 \% \mathrm{NaCl}$ and $1 \% \mathrm{HCl}$ aqueous solution, Corrosion Science 48 (2006) 20362949.

12 P. Corengia, et al., Microstructure and corrosion behavior of DC-pulsed plasma nitrided AISI 410 martensitic stainless steel, Surface and Coating Technology 187 (2004) 63-69.

13 Raghuvir Singh, S.K. Tiwari, Suman K. Mishra; Cavitation Erosion in Hydraulic Turbine Components and Mitigation by Coatings: Current Status and Future Needs, Journal of Materials Engineering and Performance, Volume 21(7) July 2012-1539

14 A.P. Tschiptschin et al.; The effect of nitrogen on the scratch resistance of austenitic stainless steels, Tribology International 39 (2006) 167-174.

\footnotetext{
* Technical contribution to the $2^{\text {nd }}$ International Brazilian Conference on Tribology - TriboBR 2014, November $3^{\text {rd }}$ to $5^{\text {th }}$, 2014, Foz do Iguaçu, PR, Brazil.
} 